JOURNAL OF SECURITY AND SUSTAINABILITY ISSUES

ISSN 2029-7017 print/ISSN 2029-7025 online

2019 March Volume 8 Number 3

http://doi.org/10.9770/jssi.2019.8.3(19)

\title{
Scopus
}

\section{INNOVATIVE PERFORMANCE AS PRECONDITION OF SUSTAINABLE AND SECURE DEVELOPMENT}

\author{
Oksana Goncharenko ${ }^{1}$, Olekcii Tohochynskyi ${ }^{2}$, Kristina Sirenko $^{3}$, Stanislav Chebonenko ${ }^{4}$, Helena Tretiak $^{5}$ \\ ${ }^{1 * 2,3,4}$ Academy of the State Penitentiary Service, Chernihiv, Honcha str. 34, Chernihiv, 14000, Ukraine \\ ${ }^{5}$ National University «Chernihiv Collegium» of T.G. Shevchenko, Hetmana Polubotka str., 53 Chernihiv, 14000, Ukraine \\ E-mail: ${ }^{1 *}$ koaduep@gmail.com
}

Received 15 March 2018; accepted 15 January 2019; published 30 March 2019

\begin{abstract}
The experience of developed countries regarding the peculiarities of investment in innovative projects, in particular the EU, USA, Japan, was analyzed. It has been proved that the strategic predicate of ensuring the country's economic security is the promotion of a favorable economic and legal, financial and resource-based support for the development of scientific and innovative activity. The tools of activation of innovative activity of organizations and corresponding regulatory mechanisms of influence of the state policy were determined. A system of critiques and factors was developed for the recognition of the innovative activity of subjects of the basic structure of ecology in five groups of types of innovations: social-economic, marketing, market-oriented, government, technical. It was revealed that the main risk factor for the development of innovations, which objectively precedes the institutional-independent activity of economic entities, is to motivate the owners of organizations for their activities. This factor acts on the social and psychological level, since, their application is a key importance, including the fact that their monitoring does not require significant expenditures.
\end{abstract}

Keywords: economic security; investments; strategic priorities; state policy; innovative activity

Reference to this paper should be made as follows: Goncharenko, O.; Tohochynskyi, O.; Sirenko, K.; Chebonenko, S. 2019. Innovative performance as precondition of sustainable and secure development, Journal of Security and Sustainable Issues 8(3): 531-544. http://doi.org/10.9770/jssi.2019.8.3(19)

JEL Classifications: F52, O39

\section{Introduction}

Stable and secure economic growth in all sectors of the economy of any country directly depends on the dynamics and the extension level of the innovation sector, knowledge-intensive industries and technologies. Ensuring rapid and dynamic economic development requires an appropriate level of technology; respectively, high-skilled staffing is necessary for the development and implementation of new innovative projects. Highly innovatiove activities, being precondition of sustainable and secure development, require additional efforts directed to the propriate protection of scientific, innovative, intellectual and informational property, protection of their infrastructure (Tvaronavičienè 2018). Ensuring sustainable innovation development is one of the goals of the safety of scientific and technological progress and the economic security of enterprises. Innovation security is to ensure a high level of security for sustainable innovation and scientific and technological development of enterprises. The issue of innovation security from the point of view of intellectual property protection, the results of scientific research and industrial designs is extremely urgent since the results of the innovation activities of an enterprise have to be legaly and physically from any kinds of infringement (Limba T. Plèta T. Agafonov K. Damkus, M. (2017); Mikhaylov, A.S.; Mikhaylova A.A.; Savchina, O.V. (2018); Korauš, A. Gombár, M. Kelemen, P. Backa, S. (2019). 
The state policy in each sphere, and especially in ensuring the development of system-functional complexes aimed at supporting basic economic activities or sectors of the economy, the real sector, should be carefully planned, calculated and implemented in the future in a strictly defined sequence, with the use of appropriate means, tools and mechanisms to achieve intermediate and final goals. This, to a large extent, recognizes its effectiveness and the achievement of targets of state regulation of the economy. Moreover, strategic planning is necessary not only for the setting of a "road map" of reform and the relevant processes, but also for monitoring how reforms in one area will affect the functioning of others, what structural changes will occur in the socioeconomic system of the state as a whole and what consequences they will have (Fabuš, M. Csabay, M. (2018); Finogentova, O. Tokarev, V. Petrenko, M. Primak, T. (2018)).

Therefore, a special relevance at the present stage of social and economic development of the state acquires the problem of determining and justifying the strategic priorities of improving investment and innovation to ensure economic security of the national economy, forecasting positive results and their achievements, the impact on the dynamics of the main macroeconomic and social parameters of the functioning and development of the state. At the same time, these guidelines should be consistent with the basic priorities of the state's economy, especially such as inclusive growth or the focus of economic development results on improving the quality of life of citizens and overcoming social inequality and injustice, building an open competitive economy based on improving the level of technology, ensuring the appropriate level of economic security of the state and its components, diversification and active development of international cooperation, improving the place of the state in the system of international division of labor (Tetiana, H., Karpenko, L., Fedoruk, O., Shevchenko, I., \& Drobyazko, S. (2018), Tetiana, H., Chorna M., Karpenko L., Milyavskiy M. \& Drobyazko S. (2018), Wu, J., Wang, C., Hong, J., Piperopoulos, P., \& Zhuo, S. (2016); Eddelani, O.; El Amrani El Idrissi, N.; Monni, S. (2019); Smaliukiene, R.; Monni, S. (2019)).

It is worth adding that the formation of the state set policy priorities in general should ensure the achievement of a certain generalizing complex effect. It is a general policy objective. Nowadays it is almost axiomatic, and we also adhere to this opinion, there is a thesis of non-alternative innovative way of development in order to ensure the competitiveness of the national economy (Hilorme, T., Nazarenko Inna, Okulicz-Kozaryn, W., Getman, O. \& Drobyazko, S. (2018); Prakash, R.; Garg, P. (2019)). The innovation factor and the application of modern and up-to-date technologies become more and more significant factor in the growth of sales and distribution of products on domestic and foreign markets. Nevertheless, we recognize that the innovative activity is based on all-in-one financial and resource-related security. Consequently, the rationalization of its volume and an increase of economic activity of the objective is based on the investment support system.

The aim of the work is the developing methodological and methodical support and practical recommendations for improving the assessment of innovative potential for the formation of an enterprise strategy. To achieve the goal, the following tasks were set and solved: to generalize the methodological approaches to justify the main point of the innovation potential as a background for strategic innovative development of an enterprise; develop the methodological research base, justify the methodological approach and develop a model for evaluating the process of innovative potential; form a scientific basis for dimension and synthesize a method for quantitative assessment of the components of the innovation potential; explore the factors influencing the formation of each group of indicators of the properties of the innovation potential (susceptibility and realization), creating a background for quantitative assessment; develop methodological support for determining the levels of properties of the innovation potential to identify areas of potential benefits and risks of innovation; justify the toolkit for selecting an innovation strategy for the enterprise; to develop measures to improve the assessment of the innovative potential of an enterprise.

The dependence of the formation of the economic security strategy of an enterprise on its ability to perceive innovation and realize it, is required an in-depth theoretical substantiation.

The task of methodological support of a comprehensive assessment of the innovation potential, as a condition for the introduction of innovations in the strategic planning period, which determined the choice of the topic 
of a scientific article, determined its logical structure, goal, object, subject and research objectives, is relevant. Based on this, the task of providing methodological support for an integrated assessment of the innovation potential, as a condition for the introduction of innovations in the strategic planning period, becomes relevant, which determined the choice of the topic of a scientific article, determined its logical structure, goal, object, subject and research objectives.

\section{Literature Survey}

The third aspect, which is important to take into account in the formulation of the general purpose of public policy in the analyzed area, is the need to ensure a comprehensive impact of increasing volumes (Lazaridis, G. (2016)), as well as the introduction of the innovation results in all spheres of public life, real sector of economy and the phases of the reproductive process for levelling or at least minimizing the negative impact of risks and threats to social and economic development of the country, such as deepening of the recession of the national economy, increasing the economic gap in comparison with other countries, reducing export potential, deepening stagnation in the investment sector, aggravation of the problem of physical and moral depreciation of fixed assets, reducing the domestic market (Zhou, Y., Chow, N., \& Xu, Y. (2017), Lee, C. (2017)) Based on the above arguments, the general goal of the state policy is to improve the investment and innovation support of the state's economic security. We are able to determine the formation of an effectively functioning independent and protected system of investment and innovation support for inclusive growth, realization of the economic potential, stable supply and strengthening of the structural and functional components of the country's economic security.

The achievement of an appropriate investment and innovation support of economic security includes the achievement of clear goals, including in terms of information transparency, ease of search and attraction of high-tech innovations in all levels of management, institutional and structural changes in the development of the national economy, the formation of intellectual and personnel support for the implementation of investment and innovation. Beside the main purpose of investment and innovative activity, of course, there is another priority task - to go through all the steps from the origination of innovative idea to sales of products to consumer with a high innovativeness content. For example, it should be noted that in the EU countries indirect investment of innovative projects is widespread, and, first and foremost, in the form of institutional platforms for the integration of scientific, research and investment activities, improvement of intellectual and personnel support of investment and innovation activities, as well as management consulting in this area. As for the forms of direct financing sources, the preference is given to venture investment and, in general, to the progress of the investment market. Along with this, the EU innovation went beyond national frames that give you the opportunity to combine the intellectual, technological and financial resourses (Collins, A. (2016), Stejskal, J., Mikušová Meričková, B., \& Prokop, V. (2016)). For example, in France, innovation policy is aimed at supporting innovative small and medium-sized enterprises, removing restrictions on venture capital investment, promoting cooperation between research institutions, universities and industrial structures. There are more than fifty technical industrial centers, contract research organizations, regional centers of innovation and transfer technology, which are engaged in organization of scientific research in the country (Robson, W. A. (2018)).

In particular, in Japan, the system of management of investment and innovation ensuring economic security of the state and performs the following functions: integration of organizational and resource capabilities of the state for the support of investment and innovation activity, the active role of corporations in supporting the activities of small innovative firms and the formation of high-quality staffing investment and innovation security. Innovation financing is mainly carried out through the Japan Development Bank, the accelerated depreciation schemes are used, so-called "soft" loans for the development of new technologies are given (onehalf of interest rates), import of high technology is stimulated, protection of new industries is carried out (Geng, Y., Fujita, T., Park, H. S., Chiu, A. S., \& Huisingh, D. (2016), Jan, S. R., Shah, S. T. U., Johar, Z. U., Shah, Y., \& Khan, F. (2016)). There is a tradition of gradual innovation "Kaizen" In the country, when enterprises deduct $8,0-10,0 \%$ of gross value added for research and development, as a result of the cost of NDR exceeding investment in new equipment (Cavelty, M. D., \& Mauer, V. (2016)). 
Venture type of financing is widely used among European countries. The highest development of venture financing are in the Great Britain, where Investment Innovation Fund is operated. The Fund's aim is the investment of technological competitive enterprises, stimulating economic growth and increasing high qualified employees (Pottier, C. (2018)). So, in Finland the technical breakthrough occurred due to the development of the venture statefunded countries for the development of the production. Conditions were created for direct investment in risky investment projects, a state investment company was founded, which invests the proceeds from the privatization of enterprises in the economy by direct investment, including the investment through venture funds. The object of investment is enterprises that are created or operate for a short time in the market. In such projects, the investment company acts as a co-investor, and active participation in such projects is implemented by industrial technologies, biotechnology, services, cellular communication (Mårtensson, K., \& Westerberg, K. (2016)).

In Israel, there is a program to support innovative business called "Yozma", which has two venture funds Yozma I and Yozma II. As a result of the investment of public funds Yozma Group in investment companies that operate in areas of technology, communication and medical fields, the country became one of the leaders in high-tech exports (Ratten, V. (2016)).

To improve the competitiveness of products, ensure its novelty and knowledge-intensive, in foreign countries scientific and industrial parks and technopolises are created. For example, in the EU there are more than a thousand units of technoparks (for example, Cambridge University, UK), in the US there are more than a hundred (in particular - silicon "Valley), more than fifty in China (in particular - Beijing experimental zone of new technologies) (Park, 2016).

\section{Methods}

The theoretical and methodological bases for the study are: the dialectical method of knowledge, the provisions of modern economic theory, system basic principles of innovation management and economic analysis.

To solve the tasks of the study were used: abstract-logical method - in assessing the innovation potential; analytical - when analyzing the economic basics of innovation, including to define the concept of "assessing the innovative potential of an enterprise on the basis of susceptibility and realization; system and situational analysis - to determine the factors influencing the decision-making regarding the choice of indicators for assessing the innovation potential; matrix modelling method - to determine the levels of properties of the innovation potential and to justify the strategy of the enterprise; correlation and factor analysis - when establishing the functional relationship between the indicators of innovation; expert method - to assess the properties of the components of the innovation potential.

This approach to the identification purpose of public policy in the analyzed field of activity is characterized by a number of features and differences in comparison with the most important targets of innovation and investment development of the country, which are determined by the authorities at the latest stage of the state, and, through this, the advantages and expectations for the best results. In our opinion, such differences are primarily:

firstly, strengthening the efficiency and capacity of subjects and participants of investment and innovation activities (which now in our country do not have the appropriate capabilities and competencies);

secondly, ensuring proper motivation, on the one hand of investors and other subjects of the financial services market, and on the other - the subjects of innovative business and enterprises of basic economic activities in relation to the production and active implementation of the results of investment activities;

thirdly, the creation of institutional infrastructure (in particular clusters, technical and implementation zones, various kinds of investment and innovation "platforms") to support and implement investment and innovation projects by all participants in this process;

fourthly, awareness of the advantages and formation of investment and innovation support of the national economy as a system that allows you to establish effective and quality interaction of all subjects of this process, 
to create an environment of irreversibility factors of activation and implementation of the results of investment and innovation;

fifthly, the focus of investment and innovation activities is not so much on development, but on ensuring the economic security of the national economy, which means the highest priority of using the achievements of investment and innovation in the basic (the most important in terms of the formation of conditions of competitiveness of the economy) economic activities, in order to strengthen export potential, protection of strategically important economic activities and business entities, sustainable, economically safe and sustainable development of the territories of the state.

Strategically, the activities should be carried out in parallel in the following areas: the formation of investment potential for the development and modernization of the national economy and the activation of innovation, increasing the use of its results in the real sector. But, we emphasize that this should not be separated from each other directions, but, on the contrary, - to develop in concert. It is appropriate to identify the common economic interests of the subjects of the system of innovation and investment support of the economy.

It is clear that on the part of the educational and research sector, venture capital organizations-a large number of orders and a high effective demand for research by business entities of the real sector of the national economy. For the subjects of the investment sector - promising profitable projects the investment in investment attractive, financially and economically effective projects, territorial economic complexes.

\section{Results}

However, the scale of such interests, their innovative specialization and strategies for further development, time guidelines, resource and infrastructure support should be defined and balanced now. The appropriate balance sheet and its structural characteristics should be guaranteed in the following time periods.

As a result of implementation of this toolkit, it is aptly to determine the creation of a national database with information on prepared and implemented investment and innovation projects, research and development work. Along with this, a separate aspect of the proper development of investment and innovation security of the state economic security should determine the coordination of national, regional and local investment innovation policy, improving the efficiency of existing tools and the formation of new (improved) ones for investment and innovation development at the local level (Chen, H. (2017)).

However, in the practice of economically developed countries, this component plays one of the decisive roles. In fact, its activities are aimed at strengthening the action of certain factors that are not a manifestation of the implementation of the actions of clearly defined entities are regulated by legislative norms, but are perceived in a certain environment and encourage its subjects to certain actions, even if not spelled out in one regulatory act. These factors operate at the social and psychological level, therefore, their introduction is very important, including the fact that their control does not require significant costs.

International experience has proven and confirmed that these measures should focus on improving the investment and financial ability of business entities to support the technical and technological modernization of their own production facilities, reducing the tax burden on micro, small and medium-sized innovative and technologically active organizations. As for the tools for this matter, we define the following measures of the targeted impact:

providing small business entities, as well as residents of technical and implementation special economic zones and technoparks with additional benefits for mandatory social payments;

direction of tax advantages on the formation of investment support for the introduction of all types of innovations (social and economic, marketing, technological, managerial, technological, technical, etc);

creation of a favorable tax regime for venture investment;

provision of tax benefits on mandatory social payments for engineering business and business in the field of 
information technology.

The structure of the innovative potential of an industrial enterprise is determined by determining the features of the susceptibility $(\mathrm{S})$ and realizability $(\mathrm{R})$ and the indicators of their estimation $\left(\mathrm{S}_{\mathrm{i}}\right.$ and $\left.\mathrm{R}_{\mathrm{i}}\right)$.

We recognize susceptibility and feasibility as the main properties of the innovation potential. Nowadays, in most studies, innovation potential is considered as an integral object, for example, a low or high innovation potential on properties and their components.

The properties of the enterprise's innovation potential (susceptibility and feasibility) are rather difficult to measure directly because they are some of the scrolls of signs or indicators, while the latter can be quantified. So, to make measurements, it is necessary to find out which values these indicators can acquire and which scales correspond to them. Therefore, one of the objectives of the research is to add the character of the ordinal or interval scale to the estimated innovation potential, that is, to move to more developed scales regarding the measurement of innovative potential, which will give more meaning to the concept of innovative potential.

Table 1 contains elements of the structure of the innovative potential of an industrial enterprise, implemented through a system of key indicators. The list of these components was developed on the basis of a survey of experts made by managers and business managers. The authors of the research developed worksheets and asked to answer the questions of experts. For the purpose of the study, the experts were selected based on the consideration that the highest degree of awareness in the question under study is held by the top and middle enterprises managers. As experts, we selected 10 officials from different control links of the management of enterprises: Private Partnership «Krivoy Rog Iron Ore Plant; Limited Partnership «SPETSRESURSY»; Limited Partnership «Metinvest» - Krivoy Rog mechanical-repair plant.

Table 1. Specification of the structure of the features of the innovative potential of an industrial enterprise and the indicators of their evaluation (author's development)

\begin{tabular}{|c|c|c|c|c|c|}
\hline $\begin{array}{l}\text { Item } \\
\text { No. }\end{array}$ & Ingredients & $\begin{array}{l}\text { Designation } \\
\text { of indicators }\end{array}$ & Table of contents of evaluation indicators & $\begin{array}{l}\text { Measurement } \\
\text { scale }\end{array}$ & $\begin{array}{l}\text { Value } \\
\text { range }\end{array}$ \\
\hline \multicolumn{6}{|c|}{ Susceptibility of Innovation Capacity (S) } \\
\hline \multirow{5}{*}{1} & \multirow{5}{*}{$\begin{array}{l}\text { Personnel } \\
\text { component }\left(\mathrm{s}_{\mathrm{k}}\right)\end{array}$} & $\mathrm{Xs}_{\mathrm{k} 1}$ & $\begin{array}{l}\text { The share of engaged in study and development in the total } \\
\text { number of personnel of the enterprise }\end{array}$ & ratio & {$[0,1]$} \\
\hline & & $\mathrm{Xs}_{\mathrm{k} 2}$ & $\begin{array}{l}\text { Highly qualified personnel reserve - the share of highly } \\
\text { qualified personnel in the total personnel of the enterprise }\end{array}$ & ratio & {$[0,1]$} \\
\hline & & $\mathrm{Xs}_{\mathrm{k} 3}$ & $\begin{array}{l}\text { The wage level of scientific and technical specialists - the } \\
\text { ratio of the volume of the wage fund of specialists engaged } \\
\text { in innovative activities to the volume of the wage fund of } \\
\text { all employees }\end{array}$ & ratio & {$[0,1]$} \\
\hline & & $\mathrm{Xs}_{\mathrm{k} 4}$ & $\begin{array}{l}\text { The total number of innovative ideas put forward by } \\
\text { employees of the company during the last periods }\end{array}$ & order & {$[0,1, \ldots, \mathrm{k}]$} \\
\hline & & $\mathrm{Xs}_{\mathrm{k} 5}$ & $\begin{array}{l}\text { Labor productivity index - the ratio of the average output } \\
\text { per worker to the maximum achieved output in the industry } \\
\text { or group of enterprises }\end{array}$ & ratio & {$[0,1]$} \\
\hline \multirow{2}{*}{2} & \multirow{2}{*}{$\begin{array}{l}\text { Information } \\
\text { component }\left(\mathrm{s}_{\text {in }}\right)\end{array}$} & $\mathrm{Xs}_{\mathrm{in} 1}$ & $\begin{array}{l}\text { The ratio of expenditures on information activities to the } \\
\text { total expenditure of the enterprise for the year }\end{array}$ & ratio & {$[0,1]$} \\
\hline & & $\mathrm{Xs}_{\mathrm{in} 2}$ & $\begin{array}{l}\text { The ratio of the number of personnel engaged in } \\
\text { information activities in the total personnel }\end{array}$ & ratio & {$[0,1]$} \\
\hline 3 & $\begin{array}{l}\text { Organizational } \\
\text { component }\left(\mathrm{s}_{0}\right)\end{array}$ & $\mathrm{Xs}_{\mathrm{o} 1}$ & The level of maturity of the enterprise & ordinal & $\begin{array}{c}{[1,2,3,} \\
4,5]\end{array}$ \\
\hline \multirow{2}{*}{4} & \multirow{2}{*}{$\begin{array}{l}\text { Motivational } \\
\text { component }\left(\mathrm{s}_{\mathrm{m}}\right)\end{array}$} & $\mathrm{Xs}_{\mathrm{ml}}$ & $\begin{array}{l}\text { The ratio of the average salary of personnel engaged in } \\
\text { innovation in the enterprise, to the maximum achieved in } \\
\text { the industry or group of enterprises }\end{array}$ & ratio & {$[0,1]$} \\
\hline & & $\mathrm{Xs}_{\mathrm{m} 2}$ & $\begin{array}{l}\text { The ratio of the amount of bonus payments for the ideas } \\
\text { presented, innovation proposals, new solutions to the total } \\
\text { amount of bonus payments for the company in recent years }\end{array}$ & ratio & {$[0,1]$} \\
\hline
\end{tabular}




\begin{tabular}{|c|c|c|c|c|c|}
\hline \multicolumn{6}{|c|}{ Realizability of innovation potential (R) } \\
\hline \multirow{4}{*}{5} & \multirow{4}{*}{$\begin{array}{l}\text { Financial } \\
\text { component }\left(r_{\mathrm{f}}\right)\end{array}$} & $\mathrm{Xr}_{\mathrm{fl}}$ & $\begin{array}{l}\text { The ratio of the costs of study and development work and } \\
\text { the cost of the acquisition of intangible assets (technology, } \\
\text { know-how) to the total expenditures of the enterprise }\end{array}$ & ratio & {$[0,1]$} \\
\hline & & $\mathrm{Xr}_{\mathrm{f} 2}$ & $\begin{array}{l}\text { The share of expenditures for advanced training and } \\
\text { personnel training in the total expenditure on study and } \\
\text { development }\end{array}$ & ratio & {$[0,1]$} \\
\hline & & $\mathrm{Xr}_{\mathrm{f} 3}$ & $\begin{array}{l}\text { The ratio of revenue from sales of new products to its total } \\
\text { volume for the analyzed period }\end{array}$ & ratio & {$[0,1]$} \\
\hline & & $\mathrm{Xr}_{\mathrm{f} 4}$ & The ratio of total revenue to energy costs per year & ratio & {$[0,1]$} \\
\hline \multirow{3}{*}{6} & \multirow{3}{*}{$\begin{array}{l}\text { Material and } \\
\text { technical component } \\
\left(\mathrm{r}_{\mathrm{m}}\right)\end{array}$} & $\mathrm{Xr}_{\mathrm{m} 1}$ & $\begin{array}{l}\text { The ratio of the average annual value of progressive } \\
\text { equipment groups to the average annual value of the active } \\
\text { part of fixed assets }\end{array}$ & ratio & {$[0,1]$} \\
\hline & & $\mathrm{Xr}_{\mathrm{m} 2}$ & $\begin{array}{l}\text { The ratio of innovative ideas introduced into production to } \\
\text { the total number of proposals put forward (or announced) }\end{array}$ & ratio & {$[0,1]$} \\
\hline & & $\mathrm{Xr}_{\mathrm{m} 3}$ & $\begin{array}{l}\text { The ratio of costs for the modernization of equipment to } \\
\text { the average annual value of the active part of fixed assets } \\
\text { of the enterprise }\end{array}$ & ratio & {$[0,1]$} \\
\hline \multirow{5}{*}{7} & \multirow{5}{*}{$\begin{array}{l}\text { Market component } \\
\left(\mathrm{r}_{\mathrm{r}}\right)\end{array}$} & $\mathrm{Xr}_{\mathrm{r} 1}$ & $\begin{array}{l}\text { The ratio of the volume of innovative products shipped to } \\
\text { the total volume of products shipped }\end{array}$ & ratio & {$[0,1]$} \\
\hline & & $\mathrm{Xr}_{\mathrm{r} 2}$ & Innovation profitability & ratio & {$[0,1]$} \\
\hline & & $\mathrm{Xr}_{\mathrm{r} 3}$ & Product prospects & ordinal & {$[1,2, \ldots 5]$} \\
\hline & & $\mathrm{Xr}_{\mathrm{r} 4}$ & $\begin{array}{l}\text { Time from the moment of initiation (filing) of a new } \\
\text { proposal to the launch of an innovative project into action }\end{array}$ & ordinal & {$[0,1, \ldots, \mathrm{k}]$} \\
\hline & & $\mathrm{Xr}_{\mathrm{r} 5}$ & $\begin{array}{l}\text { The number of new products that the company put on the } \\
\text { market for the year }\end{array}$ & ordinal & {$[0,1, \ldots, \mathrm{k}]$} \\
\hline
\end{tabular}

This made it possible to improve the efficiency of the evaluation and its practical value. Quantitative and qualitative indicators are presented in the proposed list of indicators. The quantitative indicator can be assessed in kind or in value terms. The determination of the values of quality indicators, expressed in points, was also made on the basis of expert evaluation.

The third stage: obtaining the values of individual features used for the economic evaluation of the innovation potential of the enterprise $\left(\mathrm{s}_{\mathrm{i}}\right.$ and $\left.\mathrm{r}_{\mathrm{i}}\right)$.

In the fourth stage, the information is converted into another scale if the values obtained $\left(\mathrm{s}_{\mathrm{i}}\right.$ and $\left.\mathrm{r}_{\mathrm{i}}\right)$ are not values of the ordinal scale of the type $[1, \ldots, 5]$.

If $0 \leq \mathrm{s}_{\mathrm{i}} \leq \frac{k}{5}$, then $\mathrm{s}_{\mathrm{i}}=1$; if $\frac{k}{5}<\mathrm{s}_{\mathrm{i}} \leq \frac{2 \times k}{5}$, then $\mathrm{s}_{\mathrm{i}}=2$;

if $\frac{2 \times k}{5}<\mathrm{s}_{\mathrm{i}} \leq \frac{3 \times k}{5}$, then $\mathrm{s}_{\mathrm{i}}=3$; if $\frac{3 \times k}{5}<\mathrm{s}_{\mathrm{i}} \leq \frac{4 \times k}{5}$, then $\mathrm{s}_{\mathrm{i}}=4$;

if $\frac{4 \times k}{5}<\mathrm{s}_{\mathrm{i}} \leq \mathrm{k}$, then $\mathrm{s}_{\mathrm{i}}=5$; if $0 \leq \mathrm{r}_{\mathrm{i}} \leq \frac{k}{5}$, then $\mathrm{r}_{\mathrm{i}}=1$;

if $\frac{k}{5}<\mathrm{r}_{\mathrm{i}} \leq \frac{2 \times k}{5}$, then $\mathrm{r}_{\mathrm{i}}=2$; if $\frac{2 \times k}{5}<\mathrm{r}_{\mathrm{i}} \leq \frac{3 \times k}{5}$, then $\mathrm{r}_{\mathrm{i}}=3$;

if $\frac{3 \times k}{5}<\mathrm{r}_{\mathrm{i}} \leq \frac{4 \times k}{5}$, then $\mathrm{r}_{\mathrm{i}}=4$; if $\frac{4 \times k}{5}<\mathrm{r}_{\mathrm{i}} \leq \mathrm{k}$, then $\mathrm{r}_{\mathrm{i}}=5$.

The selection of threshold values for dividing a range into intervals was carried out by an expert using unequal intervals. The fifth stage: ecaluationt of the significance of features with their constituent elements of susceptibility (S) and realizability (R) and indicators of their evaluation $\left(\mathrm{s}_{\mathrm{i}}\right.$ and $\mathrm{r}_{\mathrm{i}}$ ) are assigned specific weight. To determine the resulting ranking, the use of the Kemeny median is recommended, and to determine the coefficients of comparative importance, it is recommended to use the arithmetic average taking into account 
the statistical values corresponding to the gradations of the Harrington scale. In determining the coefficients of comparative importance of indicators characterizing the innovative potential of an enterprise, the results of both data processing methods are taken into account. At this stage, the preliminary ranking ends. The results of the evaluation of the components and their indicators in terms of their significance for calculating the potential are given in Table 2 .

Table 2. The specific weight of features, components and their indicators in the structure of the innovative potential of the enterprise (author's development)

\begin{tabular}{|c|c|c|c|}
\hline Components of innovative potential & $\begin{array}{l}\text { Weight of } \\
\text { component }\end{array}$ & Designation of evaluation indicators & $\begin{array}{l}\text { Weight of } \\
\text { indicator }\end{array}$ \\
\hline \multicolumn{4}{|c|}{ Susceptibility of innovative potential (S) } \\
\hline \multirow{6}{*}{ Personnel component $\left(\mathrm{s}_{\mathrm{k}}\right)$} & \multirow{6}{*}{0,4} & $\mathrm{Xs}_{\mathrm{k} 1}$ & 0,2 \\
\hline & & $\mathrm{Xs}_{\mathrm{k} 2}$ & 0,1 \\
\hline & & $\mathrm{Xs}_{\mathrm{k} 3}$ & 0,2 \\
\hline & & $\mathrm{Xs}_{\mathrm{k} 4}$ & 0,3 \\
\hline & & $\mathrm{Xs}_{\mathrm{k} 5}$ & 0,2 \\
\hline & & Total weight of the evaluation indicators & 1,0 \\
\hline \multirow{3}{*}{ Information component $\left(\mathrm{s}_{\mathrm{in}}\right)$} & \multirow{3}{*}{0,2} & $\mathrm{Xs}_{\mathrm{in} 1}$ & 0,4 \\
\hline & & $\mathrm{Xs}_{\mathrm{in} 2}$ & 0,6 \\
\hline & & Total weight of the evaluation indicators & 1,0 \\
\hline Organizational component $\left(\mathrm{s}_{\mathrm{o}}\right)$ & 0,2 & $\mathrm{Xs}_{\mathrm{ol}}$ & 1,0 \\
\hline \multirow{3}{*}{ Motivational component $\left(\mathrm{s}_{\mathrm{m}}\right)$} & \multirow{3}{*}{0,2} & $\mathrm{Xs}_{\mathrm{M} 1}$ & 0,3 \\
\hline & & $\mathrm{Xs}_{\mathrm{M} 2}$ & 0,7 \\
\hline & & Total weight of the evaluation indicators & 1,0 \\
\hline Total weight of the susceptibility components & 1,0 & & \\
\hline \multicolumn{4}{|c|}{ Realizability of innovation potential (R) } \\
\hline \multirow{5}{*}{ Financial component $\left(r_{f}\right)$} & \multirow{5}{*}{0,4} & $\mathrm{Xr}_{\mathrm{fl}}$ & 0,4 \\
\hline & & $\mathrm{Xr}_{\mathrm{f} 2}$ & 0,1 \\
\hline & & $\mathrm{Xr}_{\mathrm{f} 3}$ & 0,25 \\
\hline & & $\mathrm{Xr}_{\mathrm{f4}}$ & 0,25 \\
\hline & & Total weight of the evaluation indicators & 1,0 \\
\hline \multirow{4}{*}{ Material and technical component $\left(\mathrm{r}_{\mathrm{m}}\right)$} & \multirow{4}{*}{0,2} & $\mathrm{Xr}_{\mathrm{m} 1}$ & 0,4 \\
\hline & & $\mathrm{Xr}_{\mathrm{m} 2}$ & 0,4 \\
\hline & & $\mathrm{Xr}_{\mathrm{m} 3}$ & 0,2 \\
\hline & & Total weight of the evaluation indicators & 1,0 \\
\hline \multirow{6}{*}{ Market component $\left(\mathrm{r}_{\mathrm{r}}\right)$} & \multirow{6}{*}{0,4} & $\mathrm{Xr}_{\mathrm{r} 1}$ & 0,3 \\
\hline & & $\mathrm{Xr}_{\mathrm{r} 2}$ & 0,15 \\
\hline & & $\mathrm{Xr}_{\mathrm{r} 3}$ & 0,2 \\
\hline & & $\mathrm{Xr}_{\mathrm{r} 4}$ & 0,15 \\
\hline & & $\mathrm{Xr}_{\mathrm{r} 5}$ & 0,2 \\
\hline & & Total weight of the evaluation indicators & 1,0 \\
\hline Total weight of the realizability components & 1,0 & & \\
\hline
\end{tabular}

So, in the course of study, the system of elements of the internal composition of the features of the innovation potential and the indicators for their evaluation was further developed, which, unlike the existing systems, allows the analyst to apply one or several methods for assessing the level of innovation potential in the complex (linear convolution, matrix, graphics, the method of qualitative assessments).

Regarding the spread of market models for the development of innovation infrastructure, that is about the positive world experience in the functioning of innovation centers, science and technology parks and other technopark 
structures. For these entities to have their own market incentives for the creation and further functioning, it is necessary to create a favorable economic and legal environment for these processes. That is about the presence of sufficient volumes of the state order for their services, tax and other benefits and preferences, staffing and etc.

Effective state policy in this area should, of course, focus on stimulating the growth of investment and innovation activity of the subjects of the real economy sector, but also take into account the importance and priority of both sources of attracting investment resources for these purposes, and directions of development of innovative activity. That is a rational use of the state support resource and its direction for the implementation of projects with the highest level of investment and innovation attractiveness.

Table 3 presents the types of innovation selected for the survey and the corresponding indicators of innovation activity assessment.

Table 3. Criteria and indicators of evaluation of innovation activity of the real sector of the economy

\begin{tabular}{|c|c|}
\hline $\begin{array}{l}\text { Criteria (types } \\
\text { of innovation) }\end{array}$ & Evaluation indicators \\
\hline \multirow{4}{*}{ Socio-economic } & The share of innovation due to the effective use of intellectual, human resources and capital of organizations \\
\hline & Level of direct and indirect motivation of personnel for the intellectual creative activity \\
\hline & Implementation of innovations that improve the quality of life \\
\hline & The level of innovations implementation aimed at reducing the cost of goods (works, services) \\
\hline \multirow{4}{*}{ Marketing } & Diversification of forms and methods of sale goods stimulation (provision of services) \\
\hline & The level of information and analytical support for the promotion of innovative products (works, services) \\
\hline & Introduction of innovations in market research and segmentation \\
\hline & Innovativeness of payment systems for goods (works, services) \\
\hline \multirow{3}{*}{ Market } & Influence of investment activity on changes in purchasing power of the population \\
\hline & Measure of functional integration of business in the sector of investment and innovation \\
\hline & Influence on the formation of new markets or their segments \\
\hline \multirow{5}{*}{ Managerial } & Formation of internal organizational and management system of innovation development \\
\hline & Implementation of innovative approaches to business management and development \\
\hline & Availability of internal financial and resource support of innovative activity \\
\hline & $\begin{array}{l}\text { Formation of the internal infrastructure of innovation and its integration into the external system of investment and } \\
\text { innovation }\end{array}$ \\
\hline & The prevalence of innovations in the system of information and analytical support of business \\
\hline \multirow{5}{*}{ Technological } & Business process modernisation \\
\hline & Active implementation of new technological solutions in the promotion of goods (services) \\
\hline & Level of implementation of new production methods \\
\hline & Availability of security documents for intellectual property objects in relation to new technologies \\
\hline & Level of modernity of applied technologies \\
\hline
\end{tabular}

We emphasize that these results are obtained empirically using the method of the main components, the method of which replaces the expert assessment and, accordingly, this data indicates the highest dependence of the efficiency of the state policy of investment and innovation formation to ensure economic security of the national economy on the types of innovation with the highest levels of importance. This does not deny the importance of other types of innovation. However, the creation and promotion of innovative products, which have fundamentally new and better quality characteristics, is much more important to ensure the proper efficiency of investment and innovation. This is also confirmed by the close correlation between the declining in investment and innovation activity and the share of sold innovative products.

The authors are convinced that the orientation of innovation in various fields of entrepreneurship provides progressive changes not only in the production and marketing of innovative products, but also in technologies (the use of new technologies and means of production), organizational processes (new methods and forms of 
organization of all activities of companies and other elements of social production), the economy (new methods and functions of economic management through forecasting and planning, efficiency evaluation), social (new forms of human factor activation) and legal (modern advanced approaches to institutional, legal, institutional and organizational support for financial and economic activities of economic entities) spheres. And, accordingly, all these factors have a positive effect of strengthening the competitiveness of products and enterprises, increasing the efficiency of their management, readiness to respond to external and internal challenges, risks and threats and, accordingly, strengthening economic security. Moreover, it is in ensuring economic security that innovation activity is essential as a purposeful activity to create, introduce into production and promote product, technological, organizational, managerial and other innovations to the market.

\section{Discussion}

Since the objective of our study is to determine the nature (and, accordingly, the weight of the impact) of investments and innovations in the system of national economic security, on the one hand, it somewhat limits the approaches described above, and on the other - imposes additional functions. Regarding restrictions, in this area, it is the purpose and aims of investment and innovation. And in the field of security it is an ensuring a sufficient level of competitiveness of products (goods, works, services), creating conditions for economic self-sufficiency, prerequisites for development, strengthening economic stability and viability of enterprises. As for the features, these are the tasks that need to be implemented to ensure the product, financial, technical, technological, organizational and other components of economic security for economic entities.

In our opinion, the volume and effectiveness of research activities carried out by the organizations of the national economic complex and there are the non-alternative conditions for the proper restoration and long-term retention of their competitive positions in the foreign and domestic markets. Innovations give an opportunity to carry out financial and economic activity in a new and more rational, perfect way, to increase administrative and organizational, economic aspects of its efficiency, to modernize technical and technological base and business processes, to create better and more unique products. As the authors admit, the systemic risks and threats objectively hinder the investment and innovation activity of the country's economic entities, affecting mainly the motivation of the heads of organizations to such activities. However, attention is also required by another group of risks and threats that directly hinder the organization and implementation of investment and innovation activities.

These are the so-called process risks and threats that affect all stages of its business processes, that is, decision-making regarding the implementation of investments and innovations, planning of such activities, determining their scope and sources of financing, organization of cooperation with the subjects of investment and research, innovation sectors, preservation and protection of investment and innovation activities' results, their commercialization, use and economic effect.

According to this classification of threats, first of all, we pay attention to the resource and psychological prerequisites of investment and innovation activity. Thus, at the present stage of development of the national economy there is quite a significant human and institutional capacity of educational and research activities, which is positive in view of the initiation by the subjects of the real sector of measures to create and implement innovations. Note that the achievement of this actually needs the above-mentioned diversification of innovative activity of enterprises by types of its results.

\section{Conclusions}

Thus, based on the identification of innovation and the implementation areas of the objectives of investment and innovation, as well as the structuring of the security component can be argued about the complexity and importance of the task within the framework of the state policy on the formation of investment and innovation to ensure economic security of the national economy. From this, we note that most of the functional components of the security of economic entities that form investment and innovation activity, has a positive impact on 
strengthening the economic component of the security of the state, primarily macroeconomic, industrial, financial, investment, scientific and technical, foreign trade, energy, environmental protection.

Accordingly, there is every reason to state and recognize an extremely important and establishing role of investment and innovation support in the system of economic security of the each state's national economy. However, its implementation requires an effective and balanced state policy.

It is concluded that given the limitations of public and private resources, government support for investment processes and specialization of innovation should be selective and directed primarily to attract high-quality investment resources and its effective use, as well as to stimulate innovative activities with a high level of priority. In order to identify such areas, an expert sociological survey of managers and specialists of the real sector of domestic economy was conducted. The higher priority of commodity, technological, technical and marketing innovations has been established, to stimulate of which it is appropriate to attract investment resources from such sources as internal investment opportunities at own subjects expense of the real economy sector, accumulation of investment resources of integrated economic systems, subjects of the financial services market, investment state and budget support, external financial and investment resources.

\section{References}

Cavelty, M. D., \& Mauer, V. (2016). Power and security in the information age: Investigating the role of the state in cyberspace. Routledge. URL: https://books.google.com.ua/books?hl=uk\&lr=\&id=XQrPCwAAQBAJ\&oi=fnd\&pg=PP1\&dq=+economic+security+of+the+st ate\&ots $=$ mhB1AHTBuY\&sig=PI12J74U_MxB-ZBovw4ZY8k1wAU\&redir_esc $=y \# v=$ onepage \&q $=$ economic $\% 20$ security $\% 20$ of $\% 20$ the $\% 20$ state $\& \mathrm{f}=$ false

Chen, H. (2017). The institutional transition of China's township and village enterprises: market liberalization, contractual form innovation and privatization. Routledge. https://doi.org/10.4324/9781315211305

Collins, A. (2016). Contemporary security studies. Oxford university press. URL: https://books.google.com.ua/books?hl=uk\&lr=\&id=_$\mathrm{n} 7 \mathrm{CwAAQBAJ} \& \mathrm{oi}=$ fnd \&pg=PP $1 \& \mathrm{dq}=+$ economic + security + of + the + state $\&$ ots $=$ berRBvryWQ\&sig $=\mathrm{wm} 0 \mathrm{gmI} 9 \mathrm{xYkL} 4 \mathrm{~s}$ $\mathrm{fKuNyzVbq7LR} 4 \&$ redir_esc $=\mathrm{y} \# \mathrm{v}=$ onepage $\& \mathrm{q}=$ economic $\% 20$ security $\% 20 \mathrm{of} \% 20$ the $\% 20$ state $\& \mathrm{f}=$ false

Eddelani, O., El Amrani El Idrissi, N., Monni, S. (2019). Territorialized forms of production in Morocco: provisional assessment for an own model in gestation. Insights into Regional Development 1(1), 6-18. http://doi.org/10.9770/IRD.2019.1.1(1)

Fabuš, M., Csabay, M. 2018. State aid and investment: case of Slovakia. Entrepreneurship and Sustainability Issues, 6(2): 480-488. http://doi.org/10.9770/jesi.2018.6.2(1)

Finogentova, O., Tokarev, V., Petrenko, M., Primak, T. (2018). Acceptance criterion of state coercion in contemporary society. Entrepreneurship and Sustainability Issues, 6(2): 820-829. http://doi.org/10.9770/jesi.2018.6.2(23)

Geng, Y., Fujita, T., Park, H. S., Chiu, A. S., \& Huisingh, D. (2016). Recent progress on innovative eco-industrial development. Journal of Cleaner Production, 114, 1-10. https://doi.org/10.1016/j.jclepro.2015.09.051

Hilorme, T., Nazarenko, I., Okulicz-Kozaryn, W., Getman, O. \& Drobyazko, S. (2018). Innovative model of economic behavior of agents in the sphere of energy conservation. Academy of Entrepreneurship Journal, 24(3) URL: https://www.abacademies.org/journals/monthseptember-year-2018-vol-24-issue-3-journal-aej-past-issue.html

Jan, S. R., Shah, S. T. U., Johar, Z. U., Shah, Y., \& Khan, F. (2016). An Innovative Approach to Investigate Various Software Testing Techniques and Strategies. International Journal of Scientific Research in Science, Engineering and Technology (IJSRSET), Print ISSN, 2395-1990. URL: https://www.researchgate.net/profile/Fazlullah_Khan2/publication/303280520_An_Innovative_Approach_to_ Investigate_Various_Software_Testing_Techniques_and_Strategies/links/576e56e008ae842225a849ca.pdf

Karpenko, L., Serbov, M., Kwilinski, A., Makedon, V., \& Drobyazko, S. (2018). Methodological platform of the control mechanism with the energy saving technologies. Academy of Strategic Management Journal 17(5): 1939-6104-17-5-271: 1-7. Retrieved from https:// www.abacademies.org/articles/Methodological-platform-of-the-control-mechanism-1939-6104-17-5-271.pdf

Kirchner, E., \& Sperling, J. (2018). EU security governance. https://doi.org/10.7765/9781526130945.00008

Korauš, A., Dobrovič, J., Polák, J., Kelemen, P. 2019. Security position and detection of unusual business operations from science and research perspective. Entrepreneurship and Sustainability Issues, 6(3), 1070-1079. http://doi.org/10.9770/jesi.2019.6.3(15) 
Korauš, A., Gombár, M., Kelemen, P., Backa, S. (2019). Using quantitative methods to identify insecurity due to unusual business operations, Entrepreneurship and Sustainability Issues, 6(3), 1101-1012. http://doi.org/10.9770/jesi.2019.6.3(3)

Korauš, A.; Dobrovič, J.; Polák, J.; Kelemen, P. (2019). Security position and detection of unusual business operations from science and research perspective, Entrepreneurship and Sustainability Issues 6(3):1070-1079. http://doi.org/10.9770/jesi.2019.6.3(15)

Lazaridis, G. (2016). Security, insecurity and migration in Europe. Routledge. URL: https://books.google.com.ua/books?hl=uk\&lr=\&id $=\mathrm{kLfeCwAAQBAJ \& oi}=$ fnd\&pg $=\mathrm{PP} 1 \& \mathrm{dq}=+$ economic + security + of + the + state $\&$ ots $=$ mgbWFs $1 \mathrm{LdW} \&$ sig $=\mathrm{jGe} 2 \mathrm{pSwCAnTrhiDblr6b3 \textrm {LS }}$ $\mathrm{qHiM} \&$ redir_esc $=\mathrm{y} \# \mathrm{v}=$ onepage $\& \mathrm{q}=$ economic $\% 20$ security $\% 20 \mathrm{of} \% 20$ the $\% 20$ state $\& \mathrm{f}=$ false

Lee, C. (2017). The Asian turbulence: a case study in economic security. In Asia-Europe Cooperation after the 1997-1998 Asian Turbulence (pp. 33-54). Routledge. URL: https://www.taylorfrancis.com/books/e/9781351753999/chapters/10.43242F9781315192079-2

Limba T., Plèta T., Agafonov K., Damkus M. 2017. Cyber security management model for critical infrastructure. Entrepreneurship and Sustainability Issues, 4(4), 559-573. http://dx.doi.org/10.9770/jesi.2017.4.4(12)

Martensson, K., \& Westerberg, K. (2016). Corporate environmental strategies towards sustainable development. Business Strategy and the Environment, 25(1), 1-9. URL: https://onlinelibrary.wiley.com/doi/full/10.1002/bse.1852

Mikhaylov, A.S., Mikhaylova A.A., Savchina, O.V. (2018). Innovation security of cross-border innovative milieus. Entrepreneurship and Sustainability Issues, 6(2), 754-766. http://doi.org/10.9770/jesi.2018.6.2(19)

Park, S. (2016). Development of Innovative Strategies for the Korean Manufacturing Industry by Use of the Connected Smart Factory (CSF). Procedia Computer Science, 91, 744-750. https://doi.org/10.1016/j.procs.2016.07.067

Pottier, C. (2018). Local innovation and large firm strategies in Europe. In High technology industry and innovative environments (pp. 99120). Routledge. URL: https:/www.taylorfrancis.com/books/e/9781351369541/chapters/10.4324/9781315149769-5

Prakash, R.; Garg, P. 2019. Comparative assessment of HDI with Composite Development Index (CDI). Insights into Regional Development, 1(1), 57-73. http://doi.org/10.9770/IRD.2019.1.1(5)

Ratten, V. (2016). Female entrepreneurship and the role of customer knowledge development, innovation outcome expectations and culture on intentions to start informal business ventures. International Journal of Entrepreneurship and Small Business, 27(2-3), 262-272. URL: https://s3.amazonaws.com/academia.edu.documents/40530492/IJESB2702-0307 RATTEN.pdf?AWSAccessKeyId =AKIAIWOWYYGZ2Y53UL3A\&Expires=1547983059\&Signature=Iwt9geQD9dTp2tQfMsUyJ30Hh3s\%3D\&response-contentdisposition=inline $\% 3 B \% 20$ filename\%3DRatten_V._2016_Female_entrepreneurship_a.pdf

Robson, W.A. (2018). Welfare state and welfare society: illusion and reality. Routledge. https://doi.org/10.4324/9780429458682

Shuyan, L.; Fabuš, M. (2019). Study on the spatial distribution of China's Outward Foreign Direct Investment in EU and its influencing factors, Entrepreneurship and Sustainability Issues 6(3): 1080-1096. http://doi.org/10.9770/jesi.2019.6.3(16)

Smaliukiene, R.; Monni, S. (2019). A step-by-step approach to social marketing in energy transition. Insights into Regional Development, 1(1), 19-32. http://doi.org/10.9770/IRD.2019.1.1(2)

Stejskal, J., Mikušová Meričková, B., \& Prokop, V. (2016). The cooperation between enterprises: significant part of the innovation process: a case study of the Czech machinery industry. URL: https://dspace5.zcu.cz/handle/11025/22045

Tetiana, H., Chorna M., Karpenko L., Milyavskiy M. \& Drobyazko S. (2018). Innovative model of enterprises personnel incentives evaluation. Academy of Strategic Management Journal 17(3) URL: https://www.abacademies.org/journals/month-june-year-2018-vol17-issue-3-journal-asmj-past-issue.html

Tetiana, H., Karpenko, L., Fedoruk, O., Shevchenko, I., \& Drobyazko, S. (2018). Innovative methods of performance evaluation of energy efficiency project. Academy of Strategic Management Journal, 17(2), 112-110. URL: https://www.abacademies.org/articles/innovativemethods-of-performance-evaluation-of-energy-efficiency-projects-7067.html

Tvaronavičienė M. (2018). Towards internationally tuned approach towards critical infrastructure protection. Journal of Security and Sustainability Issues, 8(2): 143-150. https://doi.org/10.9770/jssi.2018.8.2(2)

Wu, J., Wang, C., Hong, J., Piperopoulos, P., \& Zhuo, S. (2016). Internationalization and innovation performance of emerging market enterprises: The role of host-country institutional development. Journal of World Business, 51(2), 251-263. https://doi.org/10.1016/j. jwb.2015.09.002

Zhou, Y., Chow, N., \& Xu, Y. (2017). Socialist Welfare in a Market Economy: Social Security Reforms in Guangzhou, China: Social Security Reforms in Guangzhou, China. Routledge. https://doi.org/10.4324/9781315196763 
Short biographical note about the contributors at the end of the article:

Oksana GONCHARENKO, Doctor of Economic Sciences, Professor, Head of Department of Economic and social disciplines, Academy of the State Penitentiary Service, Chernihiv, Ukraine

ORCID ID: orcid.org/0000-0001-6410-4966

Olekcii TOHOCHYNSKYI, Doctor of Sciences (Pedagogy), Associate Professor, Professor of the Department of Pedagogy, President of Academy of the State Penitentiary Service, Chernihiv, Ukraine

ORCID ID: orcid.org/0000-0002-8170-6237

Kristina SIRENKO, Candidate of Economic Sciences, Academy of the State Penitentiary Service, Chernihiv, Ukraine

ORCID ID: orcid.org/0000-0003-2705-0924

Stanislav CHEBONENKO, PH.D. Pedagogics, Associate Professor, Vice-rector Academy of the State Penitentiary Service, Chernihiv, Ukraine

ORCID ID: orcid.org/0000-0002-5049-6556

Helena TRETIAK, Doctor of Sciences (Pedagogics), Professor, National University «Chernihiv Collegium» of T.G. Shevchenko, Chernihiv, Ukraine

ORCID ID: orcid.org/0000-0001-6124-2597

Register for an ORCID ID:

https://orcid.org/register

This work is licensed under the Creative Commons Attribution International License (CC BY). http://creativecommons.org/licenses/by/4.0/ 